\title{
MORPHOGENIC EFFECTS OF HALOGENATED THYMIDINE ANALOGS ON DROSOPHILA
}

\section{INCORPORATION OF 5-BROMODEOXYURIDINE INTO DNA*}

R. M. RIZKl, H. A. DOUTHIT AND T. M. RIZKI

Departments of Zoology and Botany, The University of Michigan, Ann Arbor, Mich. $7_{81}$ o.f (U.S.A.) (Received August 23rd, 1971)

SUMMARY

When 5-bromodeoxyuridine is fed to Drosophila larvae, a variety of morphogenic lesions are found in the hatching adults. Experiments were undertaken to determine whether 5 -bromodeoxyuridine is incorporated into Drosophila DNA under the conditions which induce developmental modifications.

Radioautographic techniques were used to examine the distribution of $\left[{ }^{3} \mathrm{H}\right]$ bromodeoxyuridine in Drosophila larvae. Label was found in nuclei of the larval tissues and the imaginal disc cells as well as the gonads.

DNA was isolated from Drosophila larvae which were fed 5-bromodeoxyuridine alone or in the presence of a thymidylate inhibitor, and these samples were examined by $\mathrm{CsCl}$ equilibrium density-gradient centrifugation. In the presence of 5 -fluorouracil the amount of 5-bromodeoxyuridine incorporated into Drosophila DNA was increased, and this difference was reflected as a relative increase in the denser component of BUdR-DNA in $\mathrm{CsCl}$ density gradients.

\section{INTRODUCTION}

The mutagenic activity of 5 -bromodeoxyuridine (BUdR) in microbial cells depends upon its incorporation into DNA. FREESE ${ }^{4}$ suggested that this mutagenicity results from the occurrence of base pair transitions during replication of the BUdRcontaining DNA. A number of attempts to demonstrate the mutagenicity of BUdR in Drosophila melanogaster have been undertaken, but agreement regarding its effectiveness as a mutagen in this organism has not been recorded ${ }^{3,10-12}$. On the other hand, the incorporation of BUdR into the DNA of the germ cells of Drosophila under the

\footnotetext{
* This study was supported by a grant to T.M.R. from the National Science Foundation (GBI 745 ) and by an Institutional Research Grant (No. IN-4oH) to the University of Michigan from the American Cancer Society.

Abbreviations: BUdR, 5-bromodeoxyuridine; FU, 5-fluorouracil; FUdR, fluorodeoxyuridine; TdR, thymidine; TMP, thymidine monophosphate.
} 
conditions utilized in these experiments has not been demonstrated and variability in this factor might account for the discrepancies reported between these studies.

When BUdR is administered to Drosophila larvae, a variety of morphogenic lesions are found in the hatching adult flies, indicating that oral administration of BUdR can alter the differentiative processes of the imaginal disc cells ${ }^{17,18}$. Simultaneous administration of 5 -fluorouracil (FU) with BUdR markedly increases the frequency of developmental modifications. These alterations in development could be the result of BUdR incorporation into DNA or they could be due to other metabolic disturbances initiated by BUdR treatment. The present study was therefore undertaken to determine whether BUdR will be incorporated into Drosophila DNA following oral administration of the analog, to ascertain its intercellular distribution among the somatic and germ line cells, and finally, to compare the level of BUdR incorporation into Drosophila DNA in the presence and in the absence of FU. A preliminary report of this work has been presented ${ }^{\mathbf{1 6}}$.

\section{MATERIALS AND METHODS}

Larvae of the Ore- $R$ wild-type strain of Drosophila melanogaster were maintained at $24^{\circ}$ on cream of wheat medium seeded with Fleischmann's yeast. Prior to treatment with the analogs, the larvae were removed from the medium in $10 \% \mathrm{NaCl}$, rinsed with $\mathrm{I} \% \mathrm{NaClO}_{4}$, followed by thorough washing with distilled $\mathrm{H}_{2} \mathrm{O}$. They were then transferred to $250-\mathrm{ml}$ plastic beakers containing a thin layer of washed Whatman paper pulp to which the analog solutions were added.

Larvae used for the radioautographic study were placed on an aqueous solution $\left(25 \mu \mathrm{Ci} / \mathrm{ml}\right.$ ) of $\left[{ }^{3} \mathrm{H}\right] \mathrm{BUdR}$ (New England Nuclear Corporation, specific activity $8.95 \mathrm{Ci} /$ mmole) when they were $50 \mathrm{~h}$ of age. Groups of larvae were also given this same solution of $\left.{ }^{3} \mathrm{H}\right] \mathrm{BUdR}$ containing $0.15 \mathrm{mg} / \mathrm{ml}$ of $\mathrm{FU}$ (obtained through the courtesy of Dr. W. E. ScoTT, Hoffman-LaRoche, Inc.). After 6 h, the larvae were removed from the analog solutions and returned to regular cream of wheat medium. Specimens were subsequently fixed in Carnoy when they were 68 and $96 \mathrm{~h}$ of age. Paraffin sections were cut at $5 \mu$ and mounted on microscope slides. Several slides from each group were placed in o.I $\mathrm{mg} / \mathrm{ml}$ DNAase (Worthington Biochemical Corporation) in o.or $M$ phosphate buffer containing $0.003 M_{\mathrm{MgSO}_{4}}$ at $\mathrm{pH} 6.4,37^{\circ}$ for I $\mathrm{h}$. Control slides were transferred to the buffer solution for $\mathrm{I} h$. The slides were then dipped in Kodak NTB3 nuclear track emulsion at $43^{\circ}$ and stored for 9 days before development.

DNA was isolated according to the method of Ritossa et al. ${ }^{15}$ from groups of larvae which had been maintained on the following solutions for $6 \mathrm{~h}$ : (I) BUdR; (2) $\mathrm{BUdR}+\mathrm{FU}$; (3) TdR; (4) TdR $+\mathrm{FU}$; (5) FU; (6) distilled $\mathrm{H}_{2} \mathrm{O}$. For these experiments, $\left[{ }^{3} \mathrm{H}\right]$ BUdR (New England Nuclear Corp., specific activity $8.95 \mathrm{Ci} / \mathrm{mmole}$ ) was added to an aqueous solution of $\mathrm{BUdR}$ (Calbiochem) to give a final concentration of $20.8 \mu \mathrm{Ci}$ / $0.62 \mu \mathrm{mole} / \mathrm{ml}$, and $\left[{ }^{3} \mathrm{H}\right] \mathrm{TdR}$ (New England Nuclear, specific activity $6.7 \mathrm{Ci} / \mathrm{mmole}$ ) was added to an aqueous solution of $\mathrm{TdR}$ (Sigma Chemical Company) to give a final concentration of $20 \mu \mathrm{Ci} / 0.80 \mu \mathrm{mole} / \mathrm{ml}$. In experiments utilizing $\mathrm{FU}$, this analog was used at $0.15 \mathrm{mg} / \mathrm{ml}$.

The concentration of the DNA samples was determined by the method of BURTON $^{1}$ with a sample of purified calf-thymus DNA as a standard. For estimating

Mutation Res., I4 (1972) IOI-I I I 
the radioactivity of each sample, aliquots were precipitated with $10 \%$ trichloroacetic acid on Whatman filter paper No. 542, rinsed with $5 \%$ trichloroacetic acid, propanolether $(I: I)$ and finally ether. After drying, the filter papers were placed in scintillation fluid ( $0.4 \%$ PPO and $0.005 \%$ POPOP in toluene) and counted in a Nuclear Chicago Unilux I spectrometer at a counting efficiency of $19 \%$.

Analytical ultracentrifugation of Drosophila DNA was performed by the method of MESELSON et al. ${ }^{14}$ following the procedure of SCHILDKRAUT et al. ${ }^{19}$ for preparation of the $\mathrm{CsCl}$ solutions. The samples were centrifuged at $44000 \mathrm{rev} . / \mathrm{min}$ for $15^{-20} \mathrm{~h}$ in the An-D rotor of a Spinco Model E ultracentrifuge, and photographed with $260-\mathrm{nm}$ light. Densities of Drosophila DNA were calculated relative to DNA of Micrococcus lysodeikticus which was assumed to have a buoyant density of $\mathrm{I} .73 \mathrm{I} \mathrm{g} \mathrm{cm}^{-3}$.

For preparative $\mathrm{CsCl}$ gradient centrifugation, the DNA samples were centrifuged at $33000 \mathrm{rev} . / \mathrm{min}$ for $60 \mathrm{~h}$ at $\mathrm{I} 7^{\circ}$ in an SW39 rotor of a Spinco Model L. The $5-\mathrm{ml}$ cellulose nitrate tubes contained $60-70 \mu \mathrm{g}$ of DNA in $3 \mathrm{ml} \mathrm{CsCl}$ (o.or $M$ Tris, pH 8.o) which was covered with mineral oil. Fractions were collected dropwise from the bottom of the tubes. To each fraction, I ml distilled $\mathrm{H}_{2} \mathrm{O}$ was added and absorbance readings at $260 \mathrm{~nm}$ were taken in a Zeiss PMQ spectrophotometer against a distilled $\mathrm{H}_{2} \mathrm{O}$ blank. Scintillation fluid (6 parts Triton X-I00: 7 parts toluene mixture prepared as above) was then added to each sample for counting radioactivity. Counting efficiency with this system was $10 \%$.

\section{RESULTS}

Radioautographs of larvae which had ingested $\left[{ }^{3} \mathrm{H}\right] \mathrm{BUdR}$ for a period of $6 \mathrm{~h}$ showed isotope incorporation in nuclei of the imaginal disc cells as well as the larval tissues. Fig. I illustrates the confinement of $\left[{ }^{3} \mathrm{H}\right] \mathrm{BUdR}$ to the chromosomal material of the salivary gland cells. Fig. 2 is included to demonstrate the extent of the label in the imaginal disc cells. The cells are small with little surrounding cytoplasm, and sectioned material does not offer optimum conditions for localizing radioactive foci at this magnification. However, the origin of this label can be inferred by examination of similar sections of imaginal discs treated with DNAase. Such sections lack radioisotope label. When FU was fed simultaneously with $\left[{ }^{3} \mathrm{H}\right] \mathrm{BUdR}$ to larvae, radioactivity was detectable throughout the larval and imaginal tissues, and no differences in incorporation of $\left[{ }^{3} \mathrm{H}\right] \mathrm{BUdR}$ were apparent between specimens receiving $\left[{ }^{3} \mathrm{H}\right]$ BUdR + FU and those receiving only $\left[{ }^{3} \mathrm{H}\right] \mathrm{BUdR}$. Figs. 3 and 4 demonstrate the incorporation of $\left[{ }^{3} \mathrm{H}\right] \mathrm{BUdR}$ into the gonads and the retention of this isotopic label during the third larval instar. The spermatogonial cells in the anterior portion of the testis are labeled in the specimen which was fixed at $68 \mathrm{~h}$, or approx. I $2 \mathrm{~h}$ after the feeding period with the radioisotope. When specimens from this same experiment were allowed to continue development until they reached $96 \mathrm{~h}$ of age, radioisotope was found in the spermatocytes located more posteriorly in the testis.

Since the substitution of bromines for methyl groups in thymine increases the density of DNA molecules, BUdR-DNA can be separated from native DNA by centrifugation to equilibrium in a $\mathrm{CsCl}$ density gradient. In the first attempts to examine BUdR-DNA from Drosophila, samples isolated from larvae receiving the analog for $6 \mathrm{~h}$ were subjected to analytical ultracentrifugation. The density distribution of the DNA bands in these samples were indistinguishable from DNA isolated from normal 


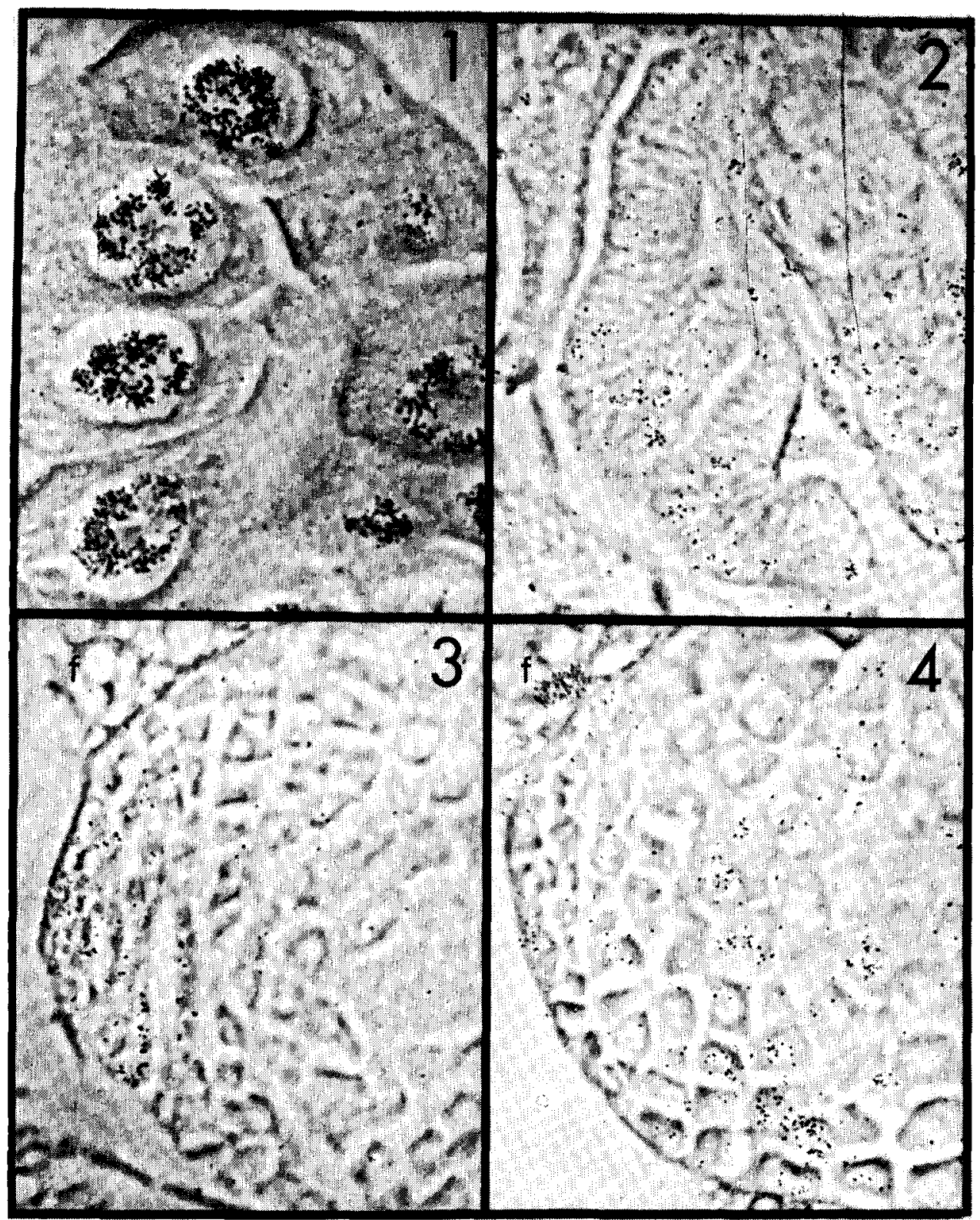

Figs. I-4. The radioautographs showing silver grains over the nuclei of various types of cells in Figs. I--4 were taken with the phase microscope by slightly moving the condenser phase ring out of alignment in order to retain some of the phase contrast to bring out the outline of the underlying tissuc and nuclei without impairing the details of the radioactive foci represented by the silver grains. Figs. I, 2 and 4 are from larvae fixed at $96 \mathrm{~h}$, or approx. $40 \mathrm{~h}$ after the BUdR - FL: pulse; Fig. 3 was taken $\mathrm{I} 2 \mathrm{~h}$ after the pulse treatment. Magnification, $\times 800$.

Iijg. I. Salivary gland cells illustrating the heavy concentration of silver grains over the nuclei as compared to the background.

Fig. 2. The retention of radioactivity in the imaginal disc cells. The nuclei of the imaginal disc cells are small $(4 \mu)$ and this section is presented to indicate the extent of radioactivity throughout the imaginal disc tissues rather than to illustrate its localization within the nuclei. DNAase treatment of similar sections removes this label.

Fig. 3. The small gonial cells of the testis showing incorporation of $\left[{ }^{3} \mathrm{H}\right\rfloor \mathrm{BU} d \mathrm{R}$. $\mathrm{f}$, fat cell.

Fig. 4. The large spermatocyte cells showing relatively high concentration of $\left[{ }^{3} \mathrm{H}\right] \mathrm{BUdR}$ at a stage $40 \mathrm{~h}$ after the analog treatment. $\mathrm{f}$, fat cell containing $\left[{ }^{3} \mathrm{H}\right] \mathrm{BUdR}$ in the nucleus. 
Drosophila larvae and no clear evidence of a density shift due to BUdR incorporation could be detected. Since the radioautographic examination had indicated that BUdR incorporation into Drosophila DNA can be accomplished by a 6-h feeding interval, it seemed likely that the amount of analog incorporated under these feeding conditions was below that detectable by the optical methods employed with analytical ultracentrifugation. Therefore, the treatment period with the analogs was lengthened in subsequent experiments to 24 and $48 \mathrm{~h}$, and distinct evidence of density changes were detectable under these conditions.

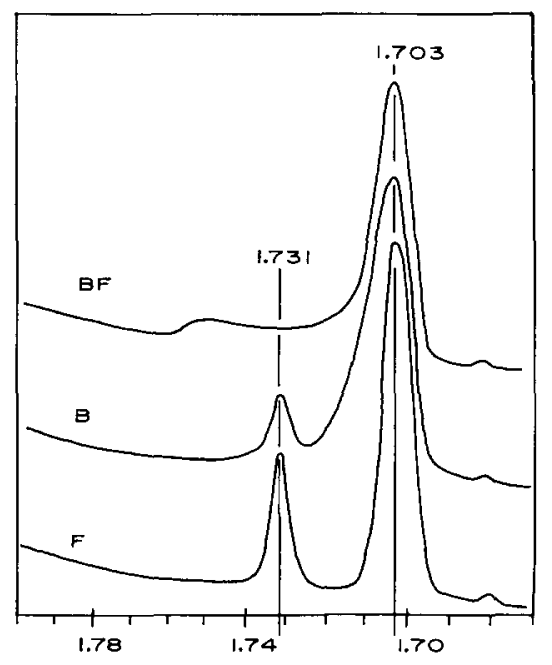

Fig. 5. Microdensitometer tracings of ultraviolet absorption photographs of Drosophila DNA samples centrifuged in CsCl. Micrococcus DNA with a buoyant density of $1.73 \mathrm{I} \mathrm{g} \mathrm{cm}^{-3}$ was used as the marker. Sample F: DNA from larvae fed FU (0.15 $\mathrm{mg} / \mathrm{ml}$ ) for $24 \mathrm{~h}$. This absorbance pattern is the same as that of DNA extracted from larvae raised on a normal diet or placed on $\mathrm{H}_{2} \mathrm{O}$ as the control. The major band has a buoyant density of $1.703 \mathrm{~g} \mathrm{~cm}^{-3}$ and a minor band appears at $1.68 \mathrm{I} \mathrm{g} \mathrm{cm}^{-3}$. Sample B: DNA from larvae given BUdR $(0.2 \mathrm{mg} / \mathrm{ml})$ for $4^{8} \mathrm{~h}$. Note the asymmetry of the main band DNA due to the denser material. Sample BF: DNA from larvae treated with $\operatorname{BUdR}(0.2 \mathrm{mg} / \mathrm{ml})$ and $\mathrm{FU}(0.15 \mathrm{mg} / \mathrm{ml})$ for $48 \mathrm{~h}$. Marker DNA was excluded from this run to illustrate the continuity of the DNA distribution from the main band to the heavier region of the gradient at $1.7 .5 \mathrm{~g} \mathrm{~cm}^{-3}$. A parallel run was performed with Micrococcus DNA as the density reference.

Microdensitometer tracings of absorbance patterns of DNA from Drosophila larvae are presented in Fig. 5. DNA samples isolated from control larvae receiving only $\mathrm{H}_{2} \mathrm{O}$ during the treatment period showed a major band with a buoyant density of $1.7036 \mathrm{~g} \mathrm{~cm}^{-3}$ and a minor component at $\mathrm{I} .68 \mathrm{I} \mathrm{g} \mathrm{cm}^{-3}$. Exposure of larvae to $\mathrm{FU}$ did not alter this distribution pattern which is illustrated in the tracing marked $\mathrm{F}$; Micrococcus DNA was added as a density marker to this cell. The sample labeled B was obtained from larvae receiving BUdR for $48 \mathrm{~h}$ and shows a prominent shoulder on the dense side of the major peak. DNA from larvae receiving $\mathrm{BUdR}+\mathrm{FU}(\mathrm{BF})$ for this same interval shows a broad shoulder with some BUdR DNA as heavy as $\mathrm{I} .75 \mathrm{~g}$ $\mathrm{cm}^{-3}$. Micrococcus DNA was excluded from the latter run to reveal the extent of the dense material in the Drosophila sample, but the buoyant density of this sample was determined from a cell containing Micrococcus DNA.

The absorbance patterns from analytical pycnography indicate a difference in 
the incorporation of BUdR into Drosophila DNA in the presence and absence of FU. On the other hand, the extended feeding intervals which were used to obtain these DNA samples are not physiologically equivalent to the brief pulse treatment $(4-6 \mathrm{~h})$ utilized to induce morphological lesions in the absence of lethality in our previous studies ${ }^{17,18}$ and to study the distribution of $\left[{ }^{3} \mathrm{H}\right] \mathrm{BUdR}$ in the radioautographic survey. Therefore, DNA samples were isolated from Drosophila larvae fed $\left[{ }^{3} \mathrm{H}\right]$-BUdR for $6 \mathrm{~h}$ and these were examined by preparative $\mathrm{CsCl}$ centrifugation so that radioactivity profiles along with the absorbance patterns of the corresponding fractions could be recorded. Larvae were also fed $\left[{ }^{3} \mathrm{H}\right] \mathrm{TdR}$ to provide radioactivity profiles of unsubstituted Drosophila DNA.

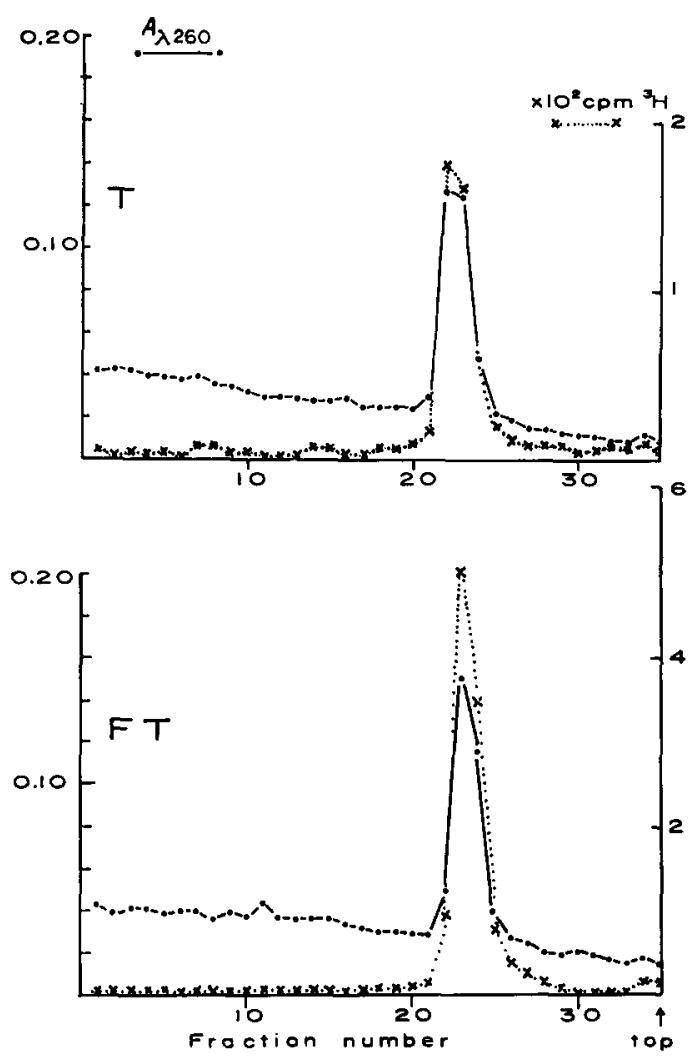

Fig. 6. $\mathrm{CsCl}$ density-gradient analysis of DNA samples from larvae fed $\left[{ }^{3} \mathrm{H}\right] \mathrm{TdR}(\mathrm{T})$ for $6 \mathrm{~h}$ and larvae fed $\left[{ }^{3} \mathrm{H}\right] \mathrm{TdR}+\mathrm{FU}(\mathrm{FT})$ for $6 \mathrm{~h}$. Note the difference in the radioactivity scale for the FT sample.

Fig. 6 (upper graph labeled T) presents the density distribution of Drosophila DNA from larvae which had been fed $\left[{ }^{3} \mathrm{H}\right] \mathrm{TdR}$ for $6 \mathrm{~h}$. There is a single peak of material absorbing at $260 \mathrm{~nm}$ and the ${ }^{3} \mathrm{H}$ radioactivity parallels the absorbance profile. When FU was fed simultaneously with $\left[{ }^{3} \mathrm{H}\right] \mathrm{TdR}$, a similar correspondence of radioactivity and absorbance peaks was obtained, but an increase in the specific activity of $\left\lceil^{3} \mathrm{H}\right\rceil \mathrm{TdR}$-DNA was apparent (FT). 


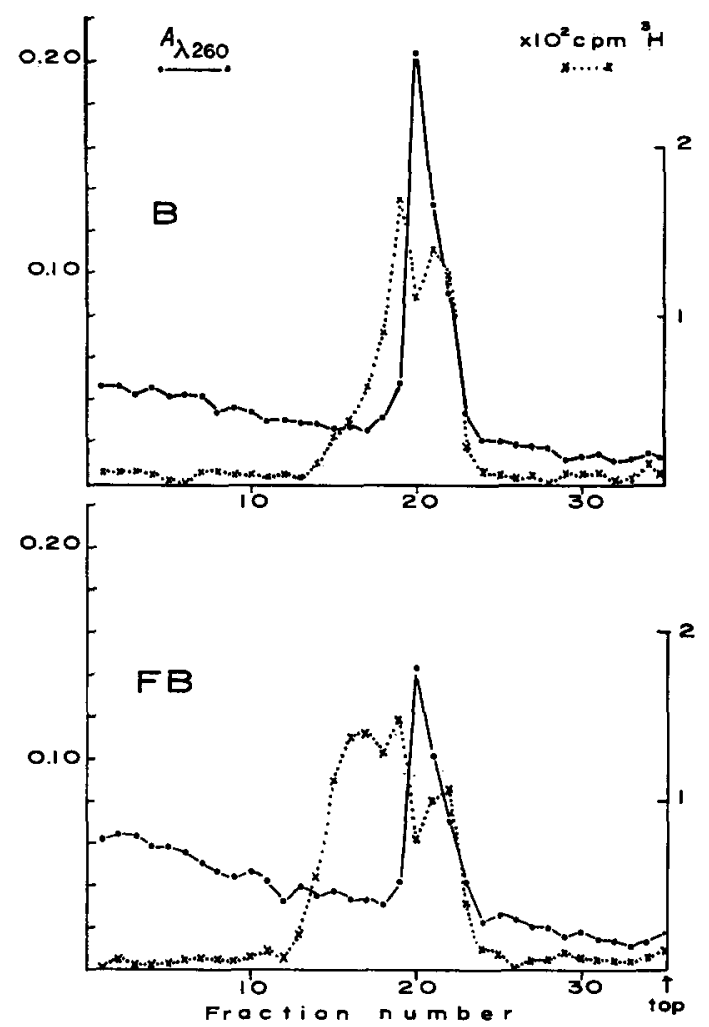

Fig. 7. Equilibrium density-gradient centrifugation in $\mathrm{CsCl}$ of DNA isolated from larvae fed $\left[{ }^{3} \mathrm{H}\right] \mathrm{BUdR}(\mathrm{B})$ for $6 \mathrm{~h}$ and from larvae fed $\left[{ }^{3} \mathrm{H}\right] \mathrm{BUdR}+\mathrm{FU}(\mathrm{FB})$ for $6 \mathrm{~h}$.

The absorbance profiles of DNA samples isolated from larvae receiving $\left[{ }^{3} \mathrm{H}\right]-$ BUdR (labeled B) and $\left[{ }^{3} \mathrm{H}\right] \mathrm{BUdR}+\mathrm{FU}$ (labeled $\mathrm{FB}$ ) for $6 \mathrm{~h}$ are presented in Fig. 7 . The feeding experiments as well as the DNA extractions for this comparison were performed simultaneously with those presented in Fig. 6. A difference in distribution of radioactivity along the gradient is apparent between the $\mathrm{B}$ and $\mathrm{FB}$ samples. $\mathrm{A}$ relative increase in radioactivity is found in the denser region of the gradient when $\mathrm{FU}$ is administered simultaneously with $\left[{ }^{3} \mathrm{H}\right] \mathrm{BUdR}$. A similar $\mathrm{CsCl}$ buoyant density comparison of $\left[{ }^{3} \mathrm{H}\right] \mathrm{BUdR}$ incorporation into DNA in the presence and in the absence of $\mathrm{FU}$ was made in 3 subsequent experiments. There was some variability in the proportion of radioactivity in the denser region of the gradient between DNA samples isolated in independent experiments, but the level attained in the denser region with $\mathrm{FU}$ always exceeded that without $\mathrm{FU}$ in any given experiment. The radioactivity profiles in the upper part of the gradients were similar in B and FB samples, and a drop in radioactivity consistently appeared under the main absorbance band of all samples segregating two distinct peaks of $\left[{ }^{3} \mathrm{H}\right]$ BUdR-DNA.

A quantitative comparison of the levels of incorporation of TdR and BUdR into Drosophila DNA in the presence and in the absence of FU is summarized in Table I. For each experiment, the larvae from a single collection period were divided into two groups, one receiving the labeled precursor with $\mathrm{FU}$ and the other receiving no $\mathrm{FU}$. 
TABLLI: I

\begin{tabular}{|c|c|c|c|c|c|}
\hline Experiment & Treatment & $A_{600}{ }^{\mathrm{a}}( \pm S . E)$. & $\begin{array}{l}\text { Counts/min b } \\
\text { (土S.E.) }\end{array}$ & $\begin{array}{l}\text { Counts/ } \\
\min \mid A\end{array}$ & $\begin{array}{l}\text { Ratio } \\
b / a\end{array}$ \\
\hline 1 & $\begin{array}{l}\text { (a) } \mathrm{TdlR} \\
\text { (b) } \mathrm{TdR}+\mathrm{FI}\end{array}$ & $\begin{array}{l}0.382( \pm 0.0069) \\
0.365( \pm 0.0002)\end{array}$ & $\begin{array}{l}847( \pm 42) \\
969( \pm 21)\end{array}$ & $\begin{array}{l}2217 \\
2655\end{array}$ & I. 20 \\
\hline 2 & $\begin{array}{l}\text { (a) } \mathrm{TdlR} \\
\text { (b) } \mathrm{TdR}+\mathrm{FL}\end{array}$ & $\begin{array}{l}0.415( \pm 0.0023) \\
0.428( \pm 0.0018)\end{array}$ & $\begin{array}{r}872( \pm 12) \\
\operatorname{II} 8\left(\begin{array}{ll}-1 & 10\end{array}\right)\end{array}$ & $\begin{array}{l}2 \mathrm{IOI} \\
26 \mathrm{I} 2\end{array}$ & I. 24 \\
\hline 3 & $\begin{array}{l}\text { (a) BIdR } \\
\text { (b) BIdR } F L\end{array}$ & $\begin{array}{l}0.605( \pm 0.0034) \\
0.5^{1} 4\left(\begin{array}{ll}1 & 0.0005)\end{array}\right.\end{array}$ & $\begin{array}{l}\text { II } 74\left(\begin{array}{ll} \pm & 23\end{array}\right) \\
\text { IIII }\left(\begin{array}{ll}t & \text { I } 4\end{array}\right)\end{array}$ & $\begin{array}{l}1940 \\
227^{8}\end{array}$ & I . I 7 \\
\hline 4 & $\begin{array}{l}\text { (a) BUdR } \\
\text { (b) BUdR + Fi: }\end{array}$ & $\begin{array}{l}0.516\left(\begin{array}{ll} \pm & 0.0005) \\
0.586( \pm & 0.0004\end{array}\right)\end{array}$ & $\begin{array}{l}1762( \pm 26) \\
2839( \pm 26)\end{array}$ & $\begin{array}{l}3415 \\
4^{8} 45\end{array}$ & 1.42 \\
\hline 5 & $\begin{array}{l}\text { (a) BUdR } \\
\text { (b) BUdR + FU }\end{array}$ & $\begin{array}{l}0.271( \pm 0.0004) \\
0.373( \pm 0.0004)\end{array}$ & $\begin{array}{r}579( \pm 20) \\
\text { I IOO }( \pm 4 I)\end{array}$ & $\begin{array}{l}2137 \\
2949\end{array}$ & I. $3^{8}$ \\
\hline
\end{tabular}

a The diphenylamine reaction was used to estimate the DNA concentration of each sample. Absorbance $\left(\dot{A}_{600}\right)$ was averaged from duplicate tests on each sample. The sample of calf-thymus DNA used as a standard gave an $A_{\lambda 600 \mathrm{~nm}}$ reading of $0.646 / 20 \%$.

$b$ The mean for radioactivity of each sample is based on triplicate determinations; each determination was counted twice for a total of $20 \mathrm{~min}$.

The concentration of the DNA samples was determined by the diphenylamine reaction, and radioactivity was counted on aliquots from each sample. In each experiment, an increase in incorporation of the radioisotope was obtained when $\mathrm{FU}$ was present during the treatment period. The DNA samples used for the preparative centrifugation studies in Figs. 6 and 7 are not included in this table since the samples were consumed for other studies. A quantitative comparison of incorporation in these four samples was therefore obtained by summing the absorbance readings of the peaks at $260 \mathrm{~nm}$ and the radioisotope counts for these regions of the gradients and designating specific activity for each of the samples as counts $/ \min / A_{260}$. The ratios of the specific activities in the presence and in the absence of $\mathrm{FU}$ were then determined for these samples: $\mathrm{ITT} / \mathrm{T}=2 . \mathrm{IO}$ and $\mathrm{FB} / \mathrm{B}=\mathrm{I} .47$.

DISCUSSION

TdR and BUdR are incorporated into DNA via the same enzymatic pathways $\left(\right.$ ClEAVER $^{2}$ ). Utilization of an exogenous supply of TdR or its analog for DNA synthesis is favored by limiting de novo synthesis of TMP in the cell. Since FUdR is a potent inhibitor of thymidylate synthetase (HEIDELBERGER ${ }^{9}$ ), it has been used in a number of studies to increase incorporation of $\mathrm{BUdR}$ into $\mathrm{DNA}^{6,8,13,21}$. It would appear that $\mathrm{FU}$ can be converted to FUdR in Drosophila, which would thus lead to increased incorporation of BUdR and TdR into DNA.

HAUT AND TAYLOR ${ }^{8}$ reported a distribution of partially substituted BUdRDNA in Vicia faba similar to that observed under the absorbance peak in the Drosophila DNA samples. BUdR incorporation in the bean roots was limited to these lighter fractions in the absence of a thymidylate inhibitor. With the use of IUdR or aminopterin during one replication cycle, however, a peak of dense BUdR-DNA appeared in the gradient at a position expected for fully substituted BUdR-DNA in Vicia, and an additional dense BUdR-DNA fraction could be obtained following 2 replication cycles in BUdR. This sequence is precisely what is expected if BUdR is 
incorporated in a semiconservative mode of DNA replication, but the occurrence of the partially substituted BUdR-DNA in Vicia presented an enigma. Substitution of BUdR via a repair mechanism, susceptibility of growing points containing BUdR to shear during DNA isolation, as well as a mode of DNA replication based on synthesis of small units may account for light fractions of $\mathrm{BUdR}-\mathrm{DNA}^{7,8,20}$. Satellite DNA was not detected in Vicia, so the possibility of BUdR incorporation in a satellite is excluded from consideration. On the other hand, Drosophila does contain a detectable satellite of lighter density than the major component, so the complication of BUdR incorporation into this fraction of DNA does have to be considered. There is no evidence for incorporation of $\left.{ }^{3} \mathrm{H}\right] \mathrm{TdR}$ into minor peaks in gradients of DNA samples obtained from Drosophila larvae following a 6 -h administration, and it is possible that further examination involving various feeding intervals of radioisotopes might provide information on the light BUdR-DNA fractions in Drosophila. In the present context, however, it should be noted that this region of the gradient is the same in samples obtained from larvae given $\mathrm{FU}$ and those receiving none. On the other hand, there is a difference in the degree of analog incorporation in the denser regions of the gradients under the two conditions of administration, and this difference is reflected in the samples following a 6 - $\mathrm{h}$ treatment as well as a longer treatment period. The incorporation of BUdR into Drosophila DNA is occurring under conditions of asynchronous cell division during a time interval which is probably less than that required for one cell cycle (Garcia-Beli.ido and Merriam ${ }^{5}$ ). The increased incorporation of BUdR into DNA in the presence of $\mathrm{FU}$ may be occurring in some of the same DNA molecules (same genes?) as in the samples without $\mathrm{FL}$; alternatively, when fed together with FU, BUdR may be distributed in an additional set of DNA molecules to give more heavier DNA, as visualized in the density gradient. Distinction between these possibilities cannot be resolved by the present analysis. In either instance, however, BUdR must be incorporated in additional stretches of DNA in the presence of $\mathrm{FU}$ and the question remains whether some of the same strands are represented in the heavier fractions of both BLdR-DNA samples.

The conditions of BUdR administration which induce morphogenic lesions in Drosophila are satisfactory for incorporation of the analog into DNA. This method employs pulse treatment with the analog in the absence of other dietary components, and perhaps these stringent conditions may favor distribution of the analog to cells throughout the organism. In various mutagenic studies with BUdR, a variety of techniques for analog administration have been utilized including addition of the analog to axenic and defined media ${ }^{10,12}$ as well as injection of the analog into adult males ${ }^{11}$. Since effective incorporation of the analog into DNA is correlated with the availability of thymidine for DNA synthesis, this factor must be evaluated for each set of conditions under which the analog is used. The conditions which we have detailed will lead to the incorporation of BUdR into Drosophila DNA in aivo in both the somatic and the germ cells.

The insertion of BUdR into a site in DNA is the primary prerequisite for its mutagenicity ${ }^{4}$. The question now to be considered is whether some of the morphogenic modifications which are induced by BUdR treatment under these conditions are due to somatic cell mutational events. A number of features are consistent with this hypothesis: the frequency of each type of somatic cell lesion induced by BUdR is low; the events are random among the individuals treated as well as among the cells of each 
wing being screened; induction of the events is not dependent on treatment during a specific period of the larval development. Evidence for the transmission of a mutant trait to descendant cells is necessary to confirm a mutagenic event, and unfortunately this information is difficult to provide in a system of somatic cells in situ. One observation does suggest that imaginal disc cells which have been altered by BUdR treatment may transmit modifications to daughter cells. This feature is the appearance of clusters of bristles in areas of the wing usually occupied by hair cells. The time of BLdR treatment is remote from the time of the definitive mitotic divisions which give rise to the four cells comprising the elements of each bristle structure. GarciaBellido and Merriam ${ }^{5}$ have recently presented a detailed study of cell multiplication in the formation of the wing of Drosophila and have estimated that a cell cycle requires approx. $8.5 \mathrm{~h}$. If cell division is not modified in BUdR-incorporated imaginal disc cells, these cells would undergo $7-8$ mitotic cycles after the treatment period used in our studies, a sequence sufficient to allow the detection of mutations due to base transitions as well as to produce clones of altered cells. Each wing represents a population of approx. $3 \cdot 10^{4}$ cells, and expression of bristle and hair characteristics in Drosophila are cell-autonomous. Therefore, clusters of similarly modified bristles found in the adult wing in place of hair cells must either be the result of a similar event occurring in a group of closely apposed stem cells in the early imaginal disc with these cells remaining side by side during subsequent development, or, a change induced in one stem cell by BUdR treatment is disseminated to descendant cells. The frequency of cluster induction by BUdR treatment is extremely low, and further experiments are required for such an analysis. If the changes observed are indeed somatic cell mutations, then the phenomenon we have studied presents an intriguing possibility of studying the effects of mutagens since the number of cells examined in a single wing is higher than the number of germ cells usually tested in mutagenesis studies.

\section{REFERENCES}

I Burton, K., A study of the conditions and mechanism of the diphenylamine reaction for the colorimetric estimation of deoxyribonucleic acid, Biochem. J., 62 (I956) 31 5-323.

2 Cleaver, J. E., Thymidine Metabolism and Cell Kinetics, North-Holland, Amsterdam, 1967.

3 FAнMY, O.G., A.D M. J. FАнMY, Mutagenesis in relation to nucleic acid synthesis in cellular genetic systems, in Z. LAvDA (Ed.), Symposium on the Mutational Process, Prague, 1965. pp. $267-282$.

+ I'ReESE, E., The specific mutagenic effect of base analogues on phage T, J. Mol. Biol., r (I959) $87-\mathrm{IO} 5$.

5 Garcia-Bellido, A., And J. R. Merriam, Parameters of the wing imaginal disc development of Drosophila melanogaster, Develop. Biol., 24 (1971) 6I-87.

6 Gause, G. F., Microbial Models of Cancer Cells, Wiley, New York, 1967.

7 Haxawalt, P. C., E. D. Pettijohn, E. C. Pauling, C. F. Brunk, D. W. Smith, L. C. Kander AND J. L. Couch, Repair replication of DNA in vivo, Cold Spring Harbor Symp. Quant. Biol., 33 (I968) I $87-194$.

8 HAUt, W. F., AND J. H. TAYlor, Studies on bromouracil deoxyriboside substitution in DNA of bean roots (Vicia faba), J. Mol. Biol., 26 (I967) 389-401.

9 Heidelierger, C., Fluorinated pyrimidines, Prog. Nucleic Acid Res. Mol. Biol., 4 (1965) $\mathbf{I}-5^{\circ}$.

10 Herskowitz, I. H., and M. Bakula, A mutational study of Drosophila grown in chemicallydefined culture, in Z. LAxDA (Ed.). Symposium on the Mutational Process, Prague, 1965 , $301-302$.

I I Kaufmand, B. P., AND H. Gay, Induction by 5-bromodeoxyuridine of sex-linked lethal mutations in spermatogenous cells of Drosophila melanogaster, Mutation Res., Io (1970) $59 \mathrm{I}-595$

I 2 Khax, A. H., AxD T. Alderson, Studies on the mutagenic activity of nucleic acid base-analogues in Drosophila, Mutation Res., 5 (I968) I 55-I6r.

Mutation Res., I4 (I972) IOI-III 
I3 Lorkiewicz, Z., AND W. SzyBalski, Genetic effects of halogenated thymidine analogs in. corporated during thymidylate synthetase inhibition, Biochem. Biophys. Res. Commun., 2 (I960) 4 I $3-4$ I 8 .

14 Meselson, M., F. W. Stahl and J. Vixograd, Equilibrium sedimentation of macromolecules in density gradients, Proc. Natl. Acad. Sci. (U.S.). 43 (I9.57) 58I-588.

i5 Ritossa, F. M., K. C. Atwood and S. Splegelman, A molecular explanation of the bobbed mutants of Drosophila as partial deficiencies of "ribosomal" DNA, Genctics, 54 (I966) 8I9-834.

I6 Rizki, T. M., Morphological modifications induced in Drosophila zygotes by 5-bromodeoxyuridine and 5-fluorouracil, Environ. Mutagen Soc., I (1970) 19-20.

I 7 Rizkı, R. M., AND T. M. Rizki, Somatic cell lesions induced by the base analog 5-bromodeoxyuridine, Cancer Res., 29 (I969) $20 \mathrm{I}-208$

is Rizki, T. M., R. M. Rizki aNd H. A. Douthit, Morphogenic effects of halogenated thymidine analogs on Drosophila, I. Quantitative analysis of lesions induced by BUdR and FU, Biochem. Genet., in the press.

I9 Schildkratt, C. L., J. Marmur axd P. Doty, Determination of the base composition of deoxyribonucleic acid from its buoyant density in $\mathrm{CsCl}, J$. Mol. Biol., 4 (1962) 430-443.

20 TAYlor, J. H., AND P. MINER, Units of DNA replication in mammalian chromosomes, Cancer Res., 28 (I968) I8IO-I8I4.

2 I Toliver, A., E. H. Simon axd P. T. Gilham, The mechanism of 5 -bromouracil inhibition of DNA synthesis and cell division, Exptl. Cell Res., 53 (I968) 506-5I8.

Mutation Res., 14 (1972) IOI-I I I 